\title{
The Analysis of Using Introducing Number Media in the Kindergarten
}

\author{
Febritesna Nuraini \\ PGPAUD FKIP \\ Universitas Ahmad Dahlan \\ Yogyakarta,Indonesia \\ Febritesna.nuraini@pgpaud.uad.ac.id
}

\author{
Dwi Hastuti; Dedi Wijayanti \\ FKIP \\ Universitas Ahmad Dahlan \\ Yogyakarta \\ Indonesia
}

\begin{abstract}
Basic skills that are maximized into the curriculum of kindergartens one of them is to know the numbers. In the daily learning activities to know the numbers do not escape the use of media prepared by the teacher. This study aims to determine the use of media to introduce numbers in Kindergarten. This research uses descriptive research method using qualitative research approach. The sample in this research is teacher and principal of 27 teachers from Kindergarten of Yogyakarta City, Bantul and Kulonprogo, who are taking a lecture at PGPAUD FKIP UAD. Based on the preliminary test results of the analysis of needs in the use of media to introduce the number is known 1) that teachers in the recognition of numbers in kindergarten still use the media Student Worksheet (LKS) and number cards, notebooks and game unloading pairs. 2) The use of media in introducing the numbers look simple other than that teachers are still using 2Dimensi, and 3) Children look less interested children when introducing numbers with the media used by teachers
\end{abstract}

Keywords : media; number; kindergarten

\section{Introduction}

The use of media in the kindergarten is important in the teaching and learning process. By using the media, the teacher can well manage the class and fulfill the principles of the learning process in the kindergarten. Learning activity in kindergarten does not only relate to the concrete thing, both concept and fact. Learning does not only relate to the concrete thing, both concept and its fact [1]. In fact, learning early childhood is complex and it is placed at the back of the fact. Based on the statement, median is used to explain the abstract things. The subtly and unclear information can be help by using the media as the mediator. In addition, media also can help the parents to explain or describe any information the children.

Media cannot be useful if it is not suitable with the objective of the usage and the teaching process. So that, the learning objective should be the parameter of the learning process and also in the usage of media. If the learning objective does not become guidance, it cannot be a supporting tool of the teaching and learning process but it can prevent the teaching process to reach the effective and efficient learning process.

The use of media can support the teaching and learning process and also important for the teacher to apply it in the kindergarten. But, as the learning agent, the teacher is more important because the teacher is an agent who facilitates the teaching and learning process in the class. The teaching and learning process is influenced by some factors, such as; teacher, students, facility, and media also environment factors. In fact, learning process usually does not run effectively and efficiently [2]. It tends to waste time, energy, and cost in order that the learning objective cannot be reached.

According to Anurrahman (2009), the success of the use of media in the teaching and learning process in the kindergarten depends on the teachers' capability in developing the learning method which is oriented in the intensity of the children's' involvement effectively in the learning process [3]. The usage of suitable learning method is to create an active and fun learning for the children in the kindergarten, so that the children can optimally grow. Besides, the teachers' knowledge about related factors of the usage of the media as a complement tool is important to create an effective learning activity. Without knowing this condition, the use of media in learning process cannot increase students' developing optimally, and the use of media cannot optimally work.

The usage of media in the learning process in kindergarten should base on the student developing aspect and objective, also base on the learning material which is suitable with children's' characteristics so that the information transferring process will be success. The use of media in learning process can increase new learning interest, motivation, and stimulation which can affect the children's' psychology.

The results of Pia Rebello Britto's research, Patrice L. Engle, and Charles M. Super (2013), Media can have negative influences on child development; we emphasize the positive potential that holistic and developmentally appropriate communication can have on young children and caregivers [5]. Communication for, with, and about young children that is inclusive and culturally sensitive can help them develop cognitively, socially, and emotionally, especially the most disadvantaged and vulnerable. It can also strengthen, be supportive of, and complement broader integrated early child development strategies and specific development goals. We review research and suggest four principles and supporting guidelines for using communication to achieve these goals. The chapter describes several examples of successful 
communication for young children from low- and middleincome countries

Introduce numbers for kindergartens cannot be separated from the role of media used by teachers. Because the media is a tool to strengthen the concept for children especially know the numbers. In line with Liedtke (1997) Kindergarten literature can strengthen the development of the language of mathematics of children. The literature referred to here is a storybook. Numerous studies have documented the potential of a child's ability to develop mathematics with a variety of activities, including counting, simple arithmetic, representation, problem solving, spatial measurement and skills, geometric knowledge and logic (Glenda Anthony \& walshaw, 2009).

In the pre-observation which is done by the researcher in the kindergarten of Yogyakarta City, the researcher delivered the learning material by using lecturing method and did not use the media yet. During this phase, the teacher delivered the material and playing activity by using student worksheet (LKA). This process was held to deliver the expected learning objective. The usage of technology in learning process is not much applied by the teacher. The researcher used HP to record and take picture of the student activities.

Based on the explanation above, the researcher is interested in studying "the analysis of the use of introducing number media in the kindergarten"

\section{METHOD}

This research method of this research is descriptive method. According to Nawawi (2001) descriptive method is the procedure of problem solving of a research by describing the subject/object of the research (someone, institution, society, etc.) based on the visible facts or real condition [5]. This research will discuss about the use of learning media in teaching and learning process in the kindergarten. The purpose of using qualitative method of this research is to gain the clear explanation about the needs of learning media in introducing the number in kindergarten.

The research subjects of this research are the headmasters and teachers of kindergarten in Yogyakarta City, Bantul and Kulonprogo. The Number subject 27 people. The data collecting technique are interview, observation, and documentation study. The data analysis of this qualitative research uses an approach by Miles and Huber man which consists of three phases; data reduction, data presentation, and conclusion/verification.

\section{RESEARCH FINDING AND DISCUSSION}

This research was held in the kindergarten of Yogyakarta City. The need analysis of the use of learning media in teaching and learning process in this research is divided into three categorizations; the types of learning media, the use of learning media in the class, and the of technology as learning media in the class.

The learning media which is used in the kindergarten based on the interview is whiteboard, drawing book, beam, tape recorder, and student worksheet. From the observation in introducing the number, teacher fells that it is more easier using the student worksheet, note books, and only few teachers which use contextual media; e.g. the student is asked to follow what the teacher says when introducing the number, for example: 'satu' is called 'S-A-T-U',so 'satu' and number card which is written on the student worksheet.

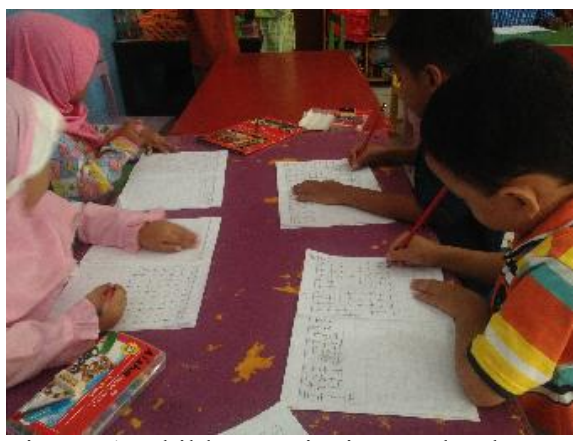

Picture.1. Children Write in Notebooks

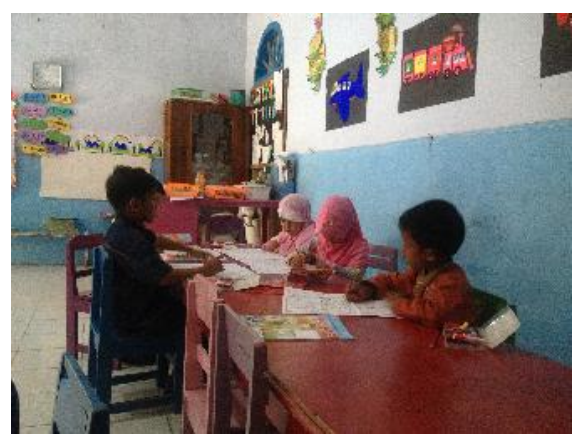

Picture.2 Activity student make worksheet

Based on the interview with the headmaster, in the learning process, it can be known that the teacher prepares the media based on the theme and subtheme of the meeting. In the introducing number activity, the teacher uses provided learning resources in the school, e.g. student worksheet (LKA) and number card as the learning media in the class.

The learning activity in introducing number, the teacher uses video and the student should watch and listen the activities in the video. 'Using video as the learning media is not too effective for the student activity, so we are very rare using video", said the one of the headmasters. It could be seen that the some students dance when the learning video was on.

The use of android phone (HP) is only for documenting and recording the student activities " $\mathrm{HP}$ is used for recording and documenting the student work'. Ms' Harti as principal, said that learning activity which is based on android have not done yet.

\section{DISCUSSION}

This research was held on the fourth week of April until May in the kindergarten of Yogyakarta City. The use of learning media in teaching and learning process is important 
for kindergarten teacher. Mursid (2015) says that media is used to complete the learning process. It is used to attract the children attention, to accelerate the teaching and learning process, and to help in completing the information which is delivered by the teacher. Besides, the use of media also can increase the teaching and learning quality. In other words, by using media in teaching and learning process can stimulate the children in learning. In addition, the use of media can increase the student motivation and interest in teaching and learning process.

The learning guidance which is used by the teacher in arranging the learning activity is an accordance government regulation, which consists of yearly program, semester program, weekly plan, and daily plan, also the standard of the performance level of student development. It is used by the teacher to arrange the lesson plan so that it can optimally success the program achievement in helping the student development.

The use of media for learning not supports the learning process so that the learning objectives not optimally are reached. This is seen when the child on the playing footing looks inactive and only completes the task of the teacher writing on note book. The teacher creativity is very needed to develop the learning media. A lot of seconds things had been recycled by the teacher to make an interesting tools game, e.g. cardboard for making the number card.

The kindergarten teacher uses some Medias to introduce number. It is a wise step in optimizing to reach the learning objective. In introducing number in the learning process, the teacher uses student worksheet (LKA). It is because LKA can facilitate the teacher in delivering information to the children. Besides, LKA can be given to their parents as connection book of the learning activity which is held in the school. By using LKA, the parents can supervise the learning activity of the children in the school.
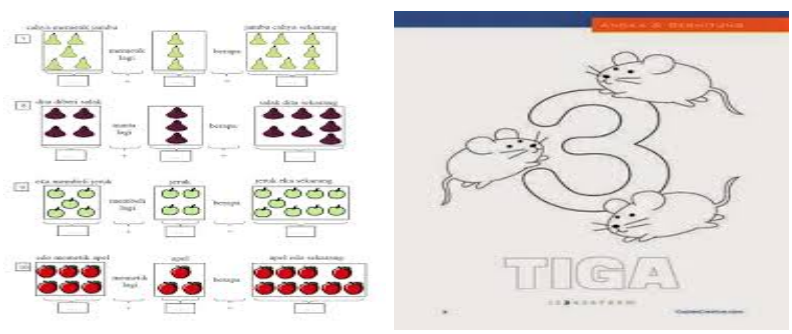

Picture.3 Child Worksheets

The strategy which is used in the school is good and effective enough in introducing the number in kindergarten in classical. Besides, the use of technology to introduce number is also done by the teacher. It can attract the student, in order that they want to actively follow the teaching and learning process.

The use of technology is done by the teacher by using the video. While the teacher uses the video, the students are divided into groups and listen to the video. So that, the student can gets information from the learning process. By using the video in introducing number give a chance for the teacher to observe and give enforcement the student activity. The enforcement which is given to the student is a LKA as the assignment. The obstacle when using the video is the electricity cable, because the children sometimes play with the cable and they will get bored.

Based on the results of observation and interviews and assessment of learning materials kindergarten, Researchers found no teacher in learning activities using software, in the form of learning devices based on HP android or smartphone for learning to know the numbers. Learning media recognize the interactive numbers, during this video, which can attract interest and help children in learning to know the numbers.

In addition, his media is contextual in the form of video, can present material that is easy to understand the child, in this case is to know the numbers. Because teachers of kindergartens already have HP android or smartphone used as a teacher documentation.

\section{CONCLUSION}

Based on the research findings and discussion, it can be concluded that the use of learning media in teaching and learning process to introduce number in kindergarten by using LKA, number card, whiteboard, and video is needed. It can be seen from the result of the observation and interview. In the teaching and learning process, the students need a media which can be activated their interest with technology-based

\section{References}

[1] Sadiman, Arief S. 2009. Education Media. Jakarta: Rajawali Pers.

[2] Wina Sanjaya.2006. Strategi Pembelajaran Berorentasi Standar Proses Pendidikan. Kencana.

[3] Aunurrahman. 2009. Learning and Learning. Bandung: Alfabeta

[4] Pia Rebello Britto's research, Patrice L. Engle, and Charles M. Super 2013. Media and early chilhood Development. Published to Oxford Scholarship Online: January 2013

[5] Nawawi. Hadari. .2001. Metode Penelitian Bidang Sosial, Gajah Mada Press: jogyakarta.

[6] Liedtke,W.1997. Fostering the development of Mathematical literacy in early chilhood. Canadian Children.

[7] Glenda Anthony \& walshaw.2009. Mathematics Education in the Early Years: Building bridges. Contemporary Issues in early Chlidhood. Volume 10 Number 2 2009. www.wwword.co.uk/CIEC

[8] Mursid, M.Ag.(2015). Belajar dan Pembelajaran PAUD.Bandung: Rosda. 